\title{
Determination of heavy metal concentration in fish samples, sediment and water from Odo-Ayo River in Ado-Ekiti, Ekiti-State, Nigeria
}

\author{
Edward J. B. *, Idowu E. O., Oso J. A., Ibidapo O. R. \\ Dept. of Zoology, Ekiti State University, Ado-Ekiti, P.M.B 5363, Ekiti State
}

Email address:

bolajiedward@yahoo.co.uk (Edward J. B.)

\section{To cite this article:}

Edward J. B., Idowu E. O., Oso J. A., Ibidapo O. R.. Determination of Heavy Metal Concentration in Fish Samples, Sediment and Water from Odo-Ayo River in Ado-Ekiti, Ekiti-State, Nigeria, International Journal of Environmental Monitoring and Analysis. Vol. 1, No. 1, 2013, pp. 27-33. doi: 10.11648/j.jema.20130101.14

\begin{abstract}
This research work was conducted to assess the concentration of heavy metals namely, $\mathrm{Zn}, \mathrm{Mn}, \mathrm{Cu}, \mathrm{Fe}, \mathrm{Pb}$ and $\mathrm{Cd}$ in three matrices including sediment, water and Fish organs (gills, flesh, kidney and liver). The fish sample, Clarias gariepinus was collected from Odo-Ayo River in Ado-Ekiti, Ekiti State, Nigeria. The results obtained showed that the concentration of heavy metal in water $(\mathrm{Zn}-4.65, \mathrm{Mn}-0.79, \mathrm{Cu}-0.84, \mathrm{Fe}-5.87, \mathrm{~Pb}-0.16, \mathrm{Cd}-0.13)$ was lower than that of the concentration of heavy metal in sediment ( $\mathrm{Zn}-5.04, \mathrm{Mn}-0.98, \mathrm{Cu}-1.37, \mathrm{Fe}-6.94, \mathrm{~Pb}-0.30, \mathrm{Cd}-0.20)$, While the concentration of heavy metals in water was higher than that of fish parts $(\mathrm{Zn}-0.95, \mathrm{Mn}-0.82, \mathrm{Cu}-0.66, \mathrm{Fe}-1.09, \mathrm{~Pb}-0.09, \mathrm{Cd}-0.04)$. This confirms that sediments are repository of metals in water. The concentration of heavy metals recorded in the fish parts also indicated a certain degree of bio-accumulation. The concentration of all metals in water were below the WHO and FEPA recommended limits and suggested that the water of Odo-Ayo River was suitable for drinking, but the bio-concentration factor of heavy metals in gills, kidney and liver of the fish are high beyond the tolerable level, which indicated that as far as these metals are concerned, the fish is unfit for human consumption. Consequently, close monitoring of metals pollution and the consumption of the fishes of Odo-Ayo River is recommended with a view to minimizing the risk of health of the population that depend on the river for their water and fish supply.
\end{abstract}

Keywords: Pollution, Heavy Metals, Fish, Odo-Ayo River

\section{Introduction}

Heavy metals are produced from a variety of natural and anthropogenic sources, they are indeed an intrinsic natural constituents of our environment. In fluvial environments, however, metal pollution can result in from direct atmospheric deposition, geologic weathering or through the discharge of agricultural, municipal or industrial waste products [1]. Apart from the natural sources, several anthropogenic ones also contribute to metal concentrations in the environment. In recent times, industrial and mechanical activities have raised natural concentrations causing serious environmental problems. Aquatic environment is one of the receiving ends for pollutants, particularly heavy metals which are ploughed back into the food chains through bioaccumulation in plankton and invertebrates to fishes and finally biomagnified in man.

Heavy metal concentrations in aquatic ecosystems are usually monitored by measuring their concentrations in water, sediments and associated biota [2], which generally exist in low levels in water and attain considerable concentration in sediment and biota [3]. Sediments are important sinks for various pollutants like pesticides and heavy metals and also play a significant role in the remobilization of contaminants in aquatic systems under favorable conditions and in interactions between water and sediments [4]. The biota that inhabits contaminated sites is generally exposed to very high concentrations of these pollutants because many of them process sediment as a food source and thus can be susceptible to bioaccumulation can potentially threaten the health of many species at the top of the food chain, especially birds, fish and humans [5]. Heavy metals including both essential and non-essential elements have a particular significance in ecotoxicology since they are highly persistent and all have the potential to be toxic to living organisms [6]. There is a considerable concern about the human health aspects of metal cycling in polluted water 
bodies that are in proximity to human settlements.

The importance of water to human has resulted in the sitting of most rural communities and industries as well as individual homes along the river course [7]. Large amounts of water consumed by humans are mainly from surface waters, which include rivers, streams, lakes, wetlands and ground water [8]. Water pollution by anthropogenic activities renders the water unfit for human consumption and recreational purposes. The Odo-Ayo River serves communities like Ilokun, Irasa and Bawa Housing Estates of AdoEkiti where farming and garri production serves as a major source of occupation for most inhabitants of these communities. Other activities like swimming, bathing, washing of clothes by the river, welding works and automobile repairing works are also a common feature of water pollution observed here.

In the recent times, Ado-Ekiti, the capital town of Ekiti state is witnessing a lot of developmental programmes especially in terms of road construction. In the light of this, there has been massive landscape disturbance due to the construction processes and heavy vehicular activities. These activities coupled with expanding human population, intensive agricultural practices and discharge of massive amount of wastewater into the river may result into deterioration of the water quality. The impact of these anthropogenic activities may be so extensive that the water body may lose its self purification capacity to a large extent. Due to inadequate municipal water supply, many inhabitants of the villages along Iworoko road depend on Odo Ayo River for their needs. The alteration in the water quality has increased the anxiety of the rural inhabitants, who have to travel great distance to other creeks for fairly good quality drinking water. Hence, Odo-Ayo River is of vital importance to these rural communities.

This present study was conducted to determine the concentration of some heavy metals in the river water and bottom sediment. This study also investigates the distribution of heavy metals in the gills, flesh, kidney and liver samples of Clarias gariepinus. Values of substances identified were compared with the internationally recommended maximum permissible levels in portable water for drinking, domestic use and for aquatic life.

\section{Materials and Method}

\subsection{Study Area}

The study was carried out in Odo-Ayo which is located along the University of Ado-Ekiti road in Ekiti State, Nigeria. It lies between latitude $7^{0} 45^{\prime} \mathrm{N}$ and $5^{0} 20^{\prime} \mathrm{E}$ of the equator. Ado-Ekiti is the capital town of Ekiti State in the Southwestern Nigeria. The samples were collected during June 2010 to December 2010.

The river takes its source from River Elemi in IgedeEkiti which itself was said to take its source from the popular Osun River in Oshogbo, Osun State. Odo-Ayo is located on a plane and is surrounded by a dense stretch of vegeta- tion and agricultural farm. The river runs across the major road leading to Iworoko-Ekiti along which the university is situated.

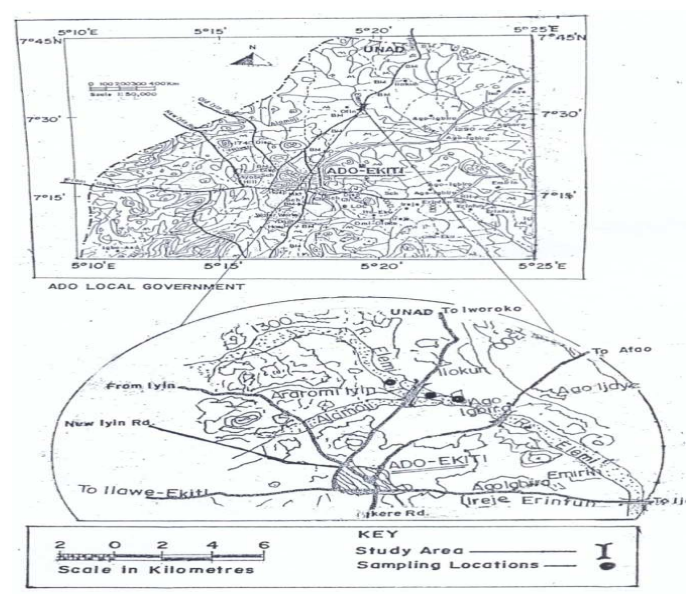

Fig. 1. The study area within Ado Ekiti showing the sampling locations.

\subsection{Sample Collection and Treatment}

Water sample was taken below the water surface in the river using one (1) liter acid-leached polythene bottles. About $0.5 \mathrm{~L}$ of the water samples were taken at each sampling site. Samples were acidified with $10 \%$ HNO3, placed in an ice bath and brought to the laboratory. The samples were filtered through a $0.45 \mu \mathrm{m}$ micropore membrane filter and kept at $40 \mathrm{C}$ until analysis. Heavy metals $(\mathrm{Zn}, \mathrm{Mn}, \mathrm{Cu}$, $\mathrm{Fe}, \mathrm{Pb}, \mathrm{Cd}$ ) were determined in the water samples using an Atomic Absorption Spectrophotometer, Perkin Elmer Model 306.

Sediment samples were collected from the sampling sites using grab sampler. Samplers were transported to the laboratory and air-dried in the laboratory at room temperature. Once air-dried, sediment samples were powdered and passed through $160 \mu \mathrm{m}$ sieve. The samples packed in polyethylene bags and stored below $-200 \mathrm{C}$ prior to analysis. Sediments samples were weighed and placed into the digestion bombs with $10 \mathrm{~mL}$ of $\mathrm{HNO} / \mathrm{HCl}(1: 3 \mathrm{v} / \mathrm{v})$ and digested in a microwave digestion system. Sediment analysis was carried out according to the procedure described earlier by [9].

Fifteen pieces of Clarias gariepinus were purchased from the fishermen at Odo-Ayo. Fish samples were transported to the laboratory in a thermos flask with ice on the same day. The length of the fish varied between $12.5 \mathrm{~cm}$ and $20.0 \mathrm{~cm}$. Their weight varied from $0.74 \mathrm{~kg}$ to $1.33 \mathrm{~kg}$. All fish samples were kept at $-300 \mathrm{C}$ until analysis. Before analysis, the fish gills, muscle, kidney and liver were removed and oven-dried at $1000 \mathrm{C}$. This was later homogenized in a blender and one gram of the homogenate was digested. A microwave digestion system (CEM Mars 5 ESP 1500 PLUS) was used to prepare the samples for analysis. Samples were mixed with $5 \mathrm{~mL}$ HNO3 (65\%) and $5 \mathrm{~mL}$ $\mathrm{H} 2 \mathrm{SO} 4$ in polypropylene vials. After 10 minutes of mixing, $1 \mathrm{~mL} \mathrm{H} 2 \mathrm{O} 2$ was added and samples were placed in a mi- 
crowave for 1 hour at $1050 \mathrm{C}$. After digestion, the residues were diluted to $25 \mathrm{~mL}$ with HNO3 $(0.3 \%)$. Determination of the elements in all samples (water, sediment and fish parts) was done in triplicates using an Atomic Absorption Spectrophotometer (Varian AA 240 FS).

\subsection{Statistical Analysis}

All data generated were analyzed statistically by calculating the mean and standard deviation of the measured parameters. The coefficient of variation and bioconcentration factors of the metals were also calculated.

\section{Results}

The result of heavy metals in water, sediment and fish sample are presented in Tables 1 and 2.

Table 1. Heavy metal concentration in water sample and sediment samples $\left(m g^{-L}\right)$.

\begin{tabular}{|c|c|c|c|c|c|c|c|c|c|c|c|c|}
\hline \multicolumn{13}{|c|}{ Metal Concentration } \\
\hline \multirow{3}{*}{$\begin{array}{l}\text { Sampling } \\
\text { Stations }\end{array}$} & \multicolumn{2}{|l|}{$Z_{n}$} & \multicolumn{2}{|l|}{ Mn } & \multicolumn{2}{|l|}{$\mathbf{C u}$} & \multicolumn{2}{|l|}{$\mathrm{Fe}$} & \multicolumn{2}{|l|}{$\mathbf{P b}$} & \multicolumn{2}{|l|}{ Cd } \\
\hline & \multicolumn{2}{|c|}{ Water Sed } & \multicolumn{2}{|c|}{ Water Sed } & \multicolumn{2}{|c|}{ Water Sed } & \multicolumn{2}{|c|}{ WaterSed } & \multicolumn{2}{|c|}{ WaterSed } & \multicolumn{2}{|c|}{ Water Sed } \\
\hline & 4.68 & 5.04 & 0.78 & 0.97 & 0.85 & 1.35 & 5.86 & 6.95 & 0.17 & 0.29 & 0.13 & 0.21 \\
\hline 2 & 4.66 & 5.04 & 0.79 & 0.98 & 0.84 & 1.37 & 5.87 & 6.93 & 0.16 & 0.31 & 0.13 & 0.20 \\
\hline 3 & 4.62 & 5.05 & 0.80 & 0.99 & 0.83 & 1.39 & 5.88 & 6.94 & 0.15 & 0.30 & 0.14 & 0.20 \\
\hline Mean & 4.65 & 5.04 & 0.79 & 0.98 & 0.84 & 1.37 & 5.87 & 6.94 & 0.16 & 0.30 & 0.13 & 0.20 \\
\hline SD & 0.02 & 0.01 & 0.01 & 0.01 & 0.01 & 0.02 & 0.01 & 0.01 & 0.01 & 0.01 & 0.01 & 0.01 \\
\hline $\mathrm{CV} \%$ & 0.49 & 0.14 & 1.27 & 1.02 & 1.19 & 1.46 & 0.17 & 0.14 & 6.25 & 3.33 & 5.39 & 5.00 \\
\hline
\end{tabular}

Note: Sed $=$ Sediment, $S D=$ Standard Deviation, $C V \%=$ Coefficient of Variation.

Table 2. Heavy metals concentration in fish parts (mg/100g).

\begin{tabular}{lllllll}
\hline Fish Part & Zn & Mn & $\mathbf{C u}$ & Fe & Pb & Cd \\
\hline Gill & 1.11 & 1.13 & 0.87 & 1.63 & 0.11 & 0.07 \\
Muscle & 0.75 & 0.49 & 0.38 & 0.63 & 0.05 & 0.01 \\
Kidney & 1.06 & 0.93 & 0.76 & 1.22 & 0.11 & 0.05 \\
Liver & 0.86 & 0.74 & 0.64 & 0.87 & 0.09 & 0.03 \\
Means & 0.95 & 0.82 & 0.66 & 1.09 & 0.09 & 0.04 \\
SD & 0.21 & 0.27 & 0.21 & 0.44 & 0.03 & 0.03 \\
CV\% & 22.11 & 32.92 & 31.82 & 40.37 & 33.33 & 75.00 \\
\hline
\end{tabular}

Note: $S D=$ Standard Deviation, $C V \%=$ Coefficient of Variation.

It was observed that generally sediment recorded the highest concentration of metals amongst the three matrices at station 3 (for zinc, manganese, copper and iron). Zinc recorded its highest concentration in sediment $(5.05 \mathrm{mg} / \mathrm{kg})$ at station 3 and had an overall mean value of $5.04 \mathrm{mg} / \mathrm{kg} \pm$ 0.01 . It has a lower concentration in water with the mean value of $4.65 \mathrm{mg} / \mathrm{L} \pm 0.02$, and the least concentration in fish muscle $(0.75 \mathrm{mg} / \mathrm{kg})$ with an overall mean value of $0.95 \mathrm{mg} / 100 \mathrm{~g} \pm 0.21$. The concentration of manganese in sediment is also the highest $(0.99 \mathrm{mg} / \mathrm{kg})$ in the three matrices with this highest value also at station 3 . It has an overall mean value of $0.98 \mathrm{mg} / \mathrm{kg} \pm 0.01$. And in water, manganese had its highest value $(0.80 \mathrm{mg} / \mathrm{L})$ at station 3 and its least $(0.78)$ at station 1 with an overall mean of $0.79 \mathrm{mg} / \mathrm{L} \pm 0.01$. The concentration of manganese was found to be higher in fish gills $(1.13 \mathrm{mg} / \mathrm{kg})$ followed by the kidney $(0.93 \mathrm{mg} / \mathrm{kg})$ least in the muscles $(0.49 \mathrm{mg} / \mathrm{kg})$. Manganese had an overall mean value of $0.82 \mathrm{mg} / \mathrm{kg}$ in the fish parts.

Copper also had its highest value $(1.39 \mathrm{mg} / \mathrm{kg})$ in sediment at station 3 and its least $(1.35 \mathrm{mg} / \mathrm{kg})$ at station 1 with an overall mean value of $1.37 \mathrm{mg} / \mathrm{kg} \pm 0.02$. It had its highest $(0.85 \mathrm{mg} / \mathrm{L})$ concentration in water at station 1 and the least $(0.83 \mathrm{mg} / \mathrm{L})$ at station 3 with an overall mean of $0.84 \mathrm{mg} / \mathrm{L} \pm 0.01$. The mean concentration of copper in water was higher than that in fish parts $(0.66 \mathrm{mg} / 100 \mathrm{~g} \pm$ $0.21)$. It however had its highest concentration in the fish gills $(0.87 \mathrm{mg} / \mathrm{kg})$ followed by the kidney $(0.76 \mathrm{mg} / \mathrm{kg})$ and the least $(0.38 \mathrm{mg} / \mathrm{kg})$ in the fish muscles. Iron concentration in sediment is the highest amongst the three matrices. It recorded the highest value of $6.95 \mathrm{mg} / \mathrm{kg}$ at station 1 and had an overall mean value of $6.94 \mathrm{mg} / \mathrm{kg} \pm 0.01$. This is followed by its concentration in water with a mean value of $5.87 \mathrm{mg} / \mathrm{L} \pm 0.01$. The lowest concentration occurred in fish muscles $(0.63 \mathrm{mg} / \mathrm{kg})$ with an overall mean value of $1.09 \mathrm{mg} / \mathrm{L} \pm 0.43$. The concentration of lead was highest in sediment, $0.31 \mathrm{mg} / \mathrm{kg}$ at station 2 and least $(0.29 \mathrm{mg} / \mathrm{kg})$ at station 1 with an overall mean value of $0.30 \mathrm{mg} / \mathrm{kg} \pm 0.01$. This was followed by water having the mean value of $0.16 \mathrm{mg} / \mathrm{L} \pm 0.01$ and the lowest concentration occurred in fish muscles $(0.05 \mathrm{mg} / \mathrm{kg})$ with the overall mean value of $0.09 \mathrm{mg} / \mathrm{L} \pm 0.03$. Cadmium was also highest in sediment $(0.21 \mathrm{mg} / \mathrm{kg})$ with the highest value at station 1 . The mean concentration of cadmium in water $(0.13 \mathrm{mg} / \mathrm{L}) \pm 0.01$ was higher than that recorded in fish parts $(0.04 \mathrm{mg} / \mathrm{kg} \pm 0.03)$. It was generally observed that amongst the fish parts, gills 
have the highest concentration of heavy metals while the muscles had the lowest concentrations.

\section{Bio-Concentration Factors of Heavy Metals}

The bio-concentration factors (BCF) of the heavy metals obtained in fish samples were as recorded below, using equation:

$$
\begin{gathered}
\mathrm{BCF}=\mathrm{C} \text { organism } \\
\mathrm{C} \text { sediment }
\end{gathered}
$$

Using equation $\mathrm{BCF}=\mathrm{C}$ organism

$$
\text { C water }
$$

$$
\begin{gathered}
\mathrm{BCF}=\mathrm{C} \text { organism } \\
\mathrm{C} \text { sediment }
\end{gathered}
$$

Where,

Corganism $=$ Concentration of metal in the organism Csediment $=$ Concentration of metal in sediment

Cwater $=$ Concentration of metal in water.

From the results of bio-concentration factor obtained in Table 3, it was observed that only lead has the highest value of 1.21. However, $\mathrm{Zn}, \mathrm{Mn}, \mathrm{Cu}, \mathrm{Fe}, \mathrm{Cd}$ with $\mathrm{BCF}$ values of $0.19,0.89,0.49,0.16,0.20$ respectively are lower than the 1.00 recommended limits of WHO/FEPA. Table 4 shows that the bio-concentration factor of heavy metals in both water and sediments was in the order
$\mathrm{Mn}>\mathrm{Cu}>\mathrm{Pb}>\mathrm{Cd}>\mathrm{Zn}>\mathrm{Fe}$.

Table 3. BCF of heavy metals in fish samples.

\begin{tabular}{llllll}
\hline Metal & Gill & Flesh & Kidney & Liver & Mean \\
\hline $\mathbf{Z n}$ & 0.22 & 0.15 & 0.21 & 0.17 & 0.19 \\
$\mathbf{M n}$ & 1.15 & 0.50 & 1.16 & 0.76 & 0.89 \\
$\mathbf{C u}$ & 0.64 & 0.28 & 0.55 & 0.47 & 0.49 \\
$\mathbf{F e}$ & 0.23 & 0.09 & 0.18 & 0.13 & 0.16 \\
$\mathbf{P b}$ & 0.37 & 0.17 & 0.37 & 0.30 & 1.21 \\
$\mathbf{C d}$ & 0.35 & 0.05 & 0.25 & 0.15 & 0.20 \\
\hline
\end{tabular}

Table 4. The bio-concentration factors of heavy metal in water and sediment.

\begin{tabular}{lllllll}
\hline Metals & $\mathbf{Z n}$ & $\mathbf{M n}$ & $\mathbf{C u}$ & $\mathbf{F e}$ & $\mathbf{P b}$ & $\mathbf{C d}$ \\
\hline Water & 0.20 & 1.04 & 0.79 & 0.19 & 0.56 & 0.31 \\
Sediment & 0.19 & 0.84 & 0.48 & 0.16 & 0.30 & 0.20 \\
Mean & 0.10 & 0.94 & 0.64 & 0.18 & 0.43 & 0.26 \\
\hline
\end{tabular}

The result of correlation coefficient between fish parts, sediments and the water of Odo-Ayo River is presented in Table 5. Fish muscle was observed to have a high positive significant correlation with water $(\mathrm{p}<0.05, \mathrm{r}=0.819)$. No visible significant correlation either at $1 \%$ or $5 \%$ level of probability with water was observed for the gills. Correlation between fish parts and sediment of Odo-Ayo showed

\begin{tabular}{|c|c|c|c|c|c|c|}
\hline & Water & & Sediment & & Fish & \\
\hline $\begin{array}{l}\text { Heavy } \\
\text { Metals }\end{array}$ & $\begin{array}{l}\text { Means of total } \\
\text { concentration } \\
\text { in present study }\end{array}$ & $\begin{array}{l}\text { Maximum } \\
\text { Limit } \\
\text { WHO/ } \\
\text { FEPA (mg/L) }\end{array}$ & $\begin{array}{l}\text { Means of } \\
\text { total concentration } \\
\text { in present study }\end{array}$ & $\begin{array}{l}\text { Maximum } \\
\text { Limit } \\
\text { WHO/ } \\
\text { FEPA(mg/kg) }\end{array}$ & $\begin{array}{l}\text { Means of total } \\
\text { concentration } \\
\text { in present study }\end{array}$ & $\begin{array}{l}\text { Maximum limit } \\
\text { WHO/ } \\
\text { FEPA (mg/kg) }\end{array}$ \\
\hline $\mathrm{Zn}$ & 4.65 & 3.000 & 5.04 & 0.0123 & 0.95 & $30(\mathrm{FAO}, 1983)$ \\
\hline $\mathrm{Mn}$ & 0.79 & 0.050 & 0.98 & 0.030 & 0.82 & 0.5 \\
\hline $\mathrm{Cu}$ & 0.84 & 1.000 & 1.37 & 0.025 & 0.66 & 3.0 \\
\hline $\mathrm{Fe}$ & 5.87 & 0.300 & 6.94 & 0.030 & 1.09 & 0.5 \\
\hline $\mathrm{Pb}$ & 0.16 & 0.010 & 0.30 & 0.040 & 0.09 & 2.0 \\
\hline $\mathrm{Cd}$ & 0.13 & 0.003 & 0.20 & 0.006 & 0.04 & 0.5 \\
\hline
\end{tabular}
that the gills exhibit no significant correlation with sediment. Sediment was observed to have high positive signifi-

\begin{tabular}{|c|c|c|c|c|c|c|}
\hline & Gills & Flesh & Kidney & Liver & Water & Sediment \\
\hline Gills & 1.000 & -0.228 & -0.232 & -0.287 & -0.081 & -0.078 \\
\hline Flesh & & 1.000 & $0.967 * *$ & $0.942 * *$ & $0.819^{*}$ & 0.810 \\
\hline Kidney & & & 1.000 & $0.924 * *$ & 0.791 & 0.800 \\
\hline Liver & & & & 1.000 & 0.585 & 0.581 \\
\hline Water & & & & & 1.000 & $0.997 * *$ \\
\hline Sediment & & & & & & 1.000 \\
\hline
\end{tabular}
cant $(\mathrm{p}<0.01, \mathrm{r}=0.997)$ correlation with water.

Table 5. International guidelines for heavy metals in water, sediment and fish.

Table 6. Correlation coefficients between fish parts, water, and sediment of Odo-Ayo River.

** Correlation is significant at the 0.01 level. * Correlation is significant at the 0.05 level. 


\section{Discussion}

In the recent times, Odo-Ayo River has been subjected to a lot of anthropogenic pollutants capable of impairing the healthy status of the river. This study revealed that all the heavy metals analyzed were found in water, sediment and fish samples of Odo Ayo River. However, the sediments accumulated more heavy metal than the water and fish samples as have been observed by numerous researchers in this area of study, such as $[10,11 ; 12,13,14 ; 15$, $16,17,18]$ to mention a few. Sediment has been known to be the major depository of metals holding more than 99 percent of total amount of a metal present in the aquatic system $[19,20,16]$. Higher concentration of metals in the sediment more than in surface water may also be connected with the fact that pollutants discharged into the aquatic environment does not remain in aqueous phase but instead are adsorbed onto the sediments. Amongst all the metals analyzed, $\mathrm{Zn}$ and $\mathrm{Fe}$ were observed to have the highest concentrations in all the water, sediment, and fish samples. All the metals were also observed to have mean values higher than the WHO/FEPA recommended limits in water and sediment samples excepts that of $\mathrm{Cu}$ which was lower in water but higher in sediments than the recommended limits.

The level of heavy metals recorded in water and fish sample in this study were generally low, when compared to the [21] and [22] recommendation. In comparison with levels in some other water bodies in other areas, [23] recorded higher metal levels in the Niger River, while [24] and [25] recorded similarly higher levels in Olomoro River and Ikpoba River, Benin city, respectively. The observed low concentrations of $\mathrm{Mn}, \mathrm{Cu}, \mathrm{Pb}, \mathrm{Cd}$ in water in this study are consistent with the finding of [13] who observed higher values only in $\mathrm{Cd}$ and $\mathrm{Pb}$ in Elechi Creek, Port Harcourt.

The higher concentration of Zinc in this study could be associated with human activities and vehicle movement that occur in the environment. Human activities such as the use of chemicals and Zinc-based fertilizers by farmers and spent engine oil wastes and petrochemicals from the nearby welder and automobile mechanic workshops could also enhance a high concentration of this metal in soils and surrounding waters. The range of $\mathrm{Zn}$ level $(0.75 \mathrm{mg} / \mathrm{kg}$ $1.11 \mathrm{mg} / \mathrm{kg}$ ) in Clarias gariepinus fish parts in this study is low when compared to the zinc level reported by [26] who recorded (10.18 - 15.28mg/100g) in Parachanna obscura from Ogba River, Benin City, Nigeria. The possible explanation for this could be difference in fish species, sizes, ages and sampling periods. Adeyeye [12] reported that differences in metal concentrations in fish were a function of species, while [24] reported that bigger fishes tend to accumulate higher concentrations of metals than smaller ones. $\mathrm{Zn}$ profile in the fish was muscles $<$ liver $<$ kidney $<$ gills. In comparison to the $30 \mathrm{mg} / \mathrm{kg}$ recommended as maximum limit for fish [21], the levels recorded in fish samples in this study were low, consequently, consumption of fish from Odo-Ayo River could not pose any Zn-induced health hazards. It is an essential mineral of importance to both plants and animal. Zinc is an essential trace metal for both plants and animals. Its deficiency may be responsible for retarded growth, loss of taste and hypogonadism, leading to decreased fertility [27]. It is necessary for embryo development and is important to reproductive organs [28].

The level of manganese (Mn) in fish samples was high especially in the gills. $\mathrm{Mn}$ is taken directly through the gills or indirectly from food and ingested sediment via gut. Mn levels in the gills, kidney and liver exceeded the [21] recommended standards of $0.5 \mathrm{mg} / \mathrm{kg}$. The levels were also high when compared to $0.016-0.043 \mathrm{mg} / 100 \mathrm{~g}$ in fish of Ikpoba River [25]. Mn profile in the fish samples were muscles $<$ liver $<$ kidney $<$ gills. Mn is an essential micronutrient for both plants and animals. Deficiencies of Mn result in severe skeletal and reproductive abnormalities in mammals. It does not occur naturally as a metal in aquatic ecosystems. It is frequently associated with iron deposits. $\mathrm{Mn}$ in aquatic environments has been attributed to detrital materials, ferromanganese minerals, clay minerals and accessory sulphide minerals [29].

Copper $(\mathrm{Cu})$ is one of the metals, which are essential to human health. It's presence in the aquatic environment may be due to accumulation of domestic and agricultural wastes. Copper combines with certain proteins to produce enzymes that act as catalyst to help in the body functions and its also necessary for the synthesis of haemoglobin [27]. The profile of $\mathrm{Cu}$ in this study was muscles $<$ liver $<$ kidney $<$ gills. Since the $\mathrm{Cu}$ recorded in this study is less than $3.00 \mathrm{mg} / \mathrm{kg}$, that is, the WHO and FEPA [21,22] permissible limit, the fish gotten from Odo-Ayo River can be consumed without the fear of poisoning from this metal. However, very high intake of $\mathrm{Cu}$ can cause adverse health effects for most living organisms.

Iron $(\mathrm{Fe})$ was found to have the highest concentration in all the samples analyzed. It has been reported that iron occurs at high concentration in Nigerian soils $[14 ; 15]$. Fe is involved in the haemoglobin synthesis in the red blood corpuscles of the blood, Fe also help with red blood cell production. It is a necessary element in human diet and plays a significant role in metabolic processes. In this study, the observed mean value of $\mathrm{Fe}$ in the fish parts far exceeded the WHO/FEPA recommended limits of $0.5 \mathrm{mg} / \mathrm{kg}$ in fish foods. Though an essential heavy metal, Fe has the tendency to become toxic to living organisms, even when exposure is low.

Lead $(\mathrm{Pb})$ level recorded in this study is due to its relatively toxicity which can be probably due to contamination of the river by the activities of car wash operators and automobiles repair workshop located in the area. $\mathrm{Pb}$ profile in the fish's organ for this study is muscles $<$ kidney $<$ gills $<$ liver. In this study, lead levels were below the recommended limits of $2.0 \mathrm{mg} / \mathrm{kg}$ for fish food. $\mathrm{Pb}$ 
and $\mathrm{Cd}$ are toxic elements which have no significant biological functions and show their carcinogenic effects on aquatic biota and humans even at low exposures. $\mathrm{Pb}$ exposure is known to cause musculo-skeletal, renal, ocular, neurological, immunological, reproductive and developmental effects [30].

Cadmium (Cd) like any other substance could be absorbed via the gills and has been known to cause damage to fish gills. In man, $\mathrm{Cd}$ poisoning could lead to anaemia, renal damage, bone disorder and cancer of the lungs [31]. Cd levels $(0.01 \mathrm{mg} / \mathrm{kg}-0.07 \mathrm{mg} / \mathrm{kg})$ recorded in fish samples from the study site were low when compared to WHO/FEPA [21,22] maximum permissible limit of $0.5 \mathrm{mg} / \mathrm{kg}$ in fish food. The levels were also low in comparison to the $0.58-1.26 \mathrm{mg} / 100 \mathrm{~g}$ recorded in fishes of Olomoro water body, [24]. [23] also recorded $0.270 \mathrm{mg} / 100 \mathrm{~g}$ for fishes of the River Niger. Cd profiles recorded in this study is lower than the permissible limits, thus, consumption of fish from Odo-Ayo River could not pose any Cd-induced health hazard.

The BCF values of the heavy metals analyzed in this study showed that bioaccumulation has occurred in the fish but not in alarming rate. Even though Clarias gariepinus is a benthic feeder, it's constant contact with the sediment does not affect its food intake to a great extent probably as a result of rapid remobilization of the adsorbed metals back into the surface waters through changes in some physicochemical parameters such as temperature, $\mathrm{pH}$, and redox potentials. Also, the phenomenon that different metals are accumulated at different concentrations in the various organs of fish was observed in this study. The difference in the levels of accumulation in the different organs/tissues of a fish can primarily be attributed to the differences in the physiological role of each organ, regulatory ability, behavior and feeding habits [32].

The gills of the examined fish has the highest concentration of all the metals, while the muscles recorded the least value and is thus the least preferred site for bioaccumulation. The high concentration of the metals in the gills could be due to element complexion with the mucus coverings in the gills which cannot be completely removed from the gill lamellae before analysis [33]. Another important influence in the total metal concentrations in the gills is the fact that metals get adsorbed onto the gills surface as the first target or point of contact for pollutants in water. Concentrations of metals were found to be generally lower in fish muscles than in the gills, kidney and liver. This is of great importance because muscles contribute the greatest mass of the flesh being consumed as food for man and other animals.

\section{Conclusion}

Heavy metals in aquatic environments are derived from natural sources (soil formation), non-point sources, transportation, domestic wastes, urban run-offs, agricultural and industrial activities. A lot of other anthropogenic activities as observed around Odo-Ayo could also contribute signifi- cantly to pollution of this water body.

The results of this finding present a valuable baseline data on the heavy metals in the water, sediments and fish from Odo-Ayo River, Ado-Ekiti, Ekiti State, Nigeria. It was observed that the concentrations of heavy metals recorded in the water samples were below the WHO \& FEPA recommended limits. However, the fact that some level of bioaccumulations was found in the fish samples from OdoAyo River is a cause for constant monitoring of the water because the surrounding villagers depend on the water downstream for domestic and agricultural purposes.

\section{References}

[1] Dawson, E,J. and Macklin, M.G. (1998). Speciation of heavy metals in floodplain and flood sediments: a reconnaissance survey of the Aire Valley, Wet Yorlshire, Great Britain. Environ. Geochem. Health 20: 67-76.

[2] Camusso, M., Vigano, L. and Baitstrini, R. (1995). Bioaccumulation of trace metals in rainbow trout. Ecotox. Environ. Safe. 31: 133-141.

[3] Namminga, H.N. and Wilhm, J. (1976). Effects of high discharge and oil refinery cleanup operation on heavy metals in water and sediments in skeleton Creek. Proceedings of the Oklahoma Academy of Science, 56: 133-138.

[4] Rashed, M.N. (2001). Monitoring of environmental heavy metals in fish from Nasser Lake. Environ. Int.. 27: 27-33.

[5] Wright, P. and Mason, C.F. (1999). Spatial and seasonal variation in heavy metals in the sediments and biota of two adjacent estuaries, the Orwell and the Stuor in Eastern England. Sci., Total Environ. 226: 139-156.

[6] Storelli, .M. M., Storelli, A., D'ddaabbo, R., Morano, C.,Bruno, R., Marcotrigiano, G.O. (2005). Trace elements in loggerhead turtles (Caretta caretta) from the eastern Mediterrenean Sea: Overview and evaluation. Environ. Pollut., 135:163-170.

[7] Egborge, A.B.M. (1982). The chemical hydrology of River Osun, Western State, Nigeria. Freshwater Biology 1:257271.

[8] Thurman, R. and Foulkner, B.(1998). Water quality in rural Australia. Journal of Applied Microbiology 84: 627-632.

[9] Binning, K and Baird, D. (2001). Survey of heavy metals in the sediments of Swartkops River Estuary, Port Elizabeth, South Africa. Water SA., 27: 461-466.

[10] Bowler H.J, (1979). Heavy metals in the sediment of foundry cover cold spring, New York. Environment Science of Technology. B. 683-687.

[11] Adeyeye, E.I. (1994). Determination of trace heavy metals in illisha africana, Fish and associated water and soil sediments from some fish ponds. International Journal of Environmental Studies. 45: 231-240.

[12] Adeyeye, E.I. (1996). Determination of trace/heavy metals in fish associated water and soil sediments from some fresh water ponds. Bangladesh Journal of Science and Industrial Research 2: 36-44. 
[13] Obire, O., Tamuno D.C., and Wemedo, S.A. (2003). Physico-chemical quality of Elechi Creek in Port-Harcourt, Nigeria. Journal of Applied Science and Environmental Management. Vol. 7(1): 43-50.

[14] Asaolu, S.S, and Olaofe, O. (2004). Bio-magnification factors of some heavy and essential metal in sediments, fish and crayfish from Ondo State Coastal Region. Biological Science Research 6:13-39.

[15] Asaolu, S.S., Ipinmoroti, , K.O., Olaofe, O., and Adeeyinwo, C.E. (1997): Interrelationship of metal concentration in water, sediment and fish samples from Ondo Coastal area, Nigeria. African Journal of Science Vol (1): 55-61.

[16] Aderinola, O.J., Clarke, E.O., Olarinmoye, O.M., Kusemiju, V. and Anatekhai, M.A. (2009). Heavy metals in surface waters, sediments and periwinkles of Lagos lagoon. American-Eurasian J. Agric. \& Environmental Sci., 5(5): 609-617.

[17] Adejare, L.I., Balogun, K.J. and Shelle, R.O.(2011): Hydrochemistry and levels of some heavy metals in samples of Ibeshe, Lagos lagoon complex, Nigeria. Journal of American Science, 7(1): 625-632.

[18] Ambedkar, G. and Muniyan, M. (2012). Analysis of heavy metals in water, sediments and selected freshwater fish collected from Gadilam River, Tamilnadu, India. International Journal of Toxicology and Applied Pharmacology 2(2): 2530 .

[19] Demirak, A., Yilmaz, F., Tuna, A.L., and Ozdemir, N. (2006). Heavy metals in water, sediment and tissues of Leuciscus cephalus from a stream in southwestern Turkey. Chemosphere 63: 1451-14-58.

[20] Ozturk, M. Ozozen, G., Minareci, O., and Minareci, E. (2009). Determination of heavy metals in fish, water and sediments of Avsdar Dam Lake in Turkey. Iran J. Environ. Health Sci. Eng. 6(2): 73-80.

[21] WHO (World Health Organization) (2003). Guidelines for Drinking Water Quality. Vol 1. Recommendation WHO. Geneva 130p.

[22] Federal Government Protection Agency (FEPA), (2003). Guidelines and Standards For Environmental Pollution Control in Nigeria. 238p.
[23] Okoronkwo, I.P. (1992). Heavy metals content in water and fish of River Niger at Yelwa-Yauri. M.Sc. Thesis. University of Benin. Benin City, Nigeria. 88p.

[24] Idodo-Umeh G. (2002). Pollution assessments of Olomoro water bodies using physical, chemical and biological indices: Thesis, University of Benin, Benin City, Nigeria, 485p.

[25] Oguzie, F.A. (2003). Heavy metals in water and sediments of the lower Ikpoba River, Benin City, Nigeria. Pakistan Journal of Science and Industrial Research. Vol. 46(3):156160.

[26] Obasohan E.E. (2007), Heavy metals concentrations in the offal, gill, muscle and liver of a fresh water mudfish (Parachanna obscura) from Ogba River, Benin city, Nigeria. African Journal of Biotechnology Vol. 6 (22): 2620-2627.

[27] Sivaperumal, P. Sankar T.V., Nair Viswanathan, P.G. (2007). Heavy metals concentration in fish, shellfish and fish products from internal markets of India vis-avis international standards. Food Chemistry. 102, 612-620.doi: 10.1016/j.foodchem.2006.05.041.

[28] Carpene, E.Gmiero B., Fedrizzi, G. and Serra, R. (1994). Trace metals $(\mathrm{Zn}, \mathrm{Cu}$ and $\mathrm{Cd})$ in fish from rearing ponds of Emilia-Romagna region (Italy). Sci Total Environ. 141: 139-146.

[29] Laar, C., Fianko, J.R., Akiti, T.T., Osei, J., Brimah, A.K., Osae, S., and Bam, E.K. (2011). Determination of trace elements in the Sakumo wetland sediments. Research Journal of Environmental and Earth Sciences 3(4): 417-421.

[30] ATSDR (Toxicological Profile for Lead) (1999). US Department of Health and Human Services, Public Health Services 205-93-0606.

[31] Ademoroti, C.M.A. (1996). Standard Methods for Water and Effluents Analysis. Foludex Press Ltd., Ibadan, 182p.

[32] Marzouk M. (1994). Fish and environmental pollution. Vet. Med. J., 42: 51-52.

[33] Khalil, M and Faragallah, H. (2008). The distribution of some leachable and total heavy metals in core sediments of Manzala lagoon, Egypt. J. Aquat. Res., 34(1): 1-11. 